\title{
Relationship of Physical Performance with Body Composition and Bone Mineral Density in Individuals over 60 Years of Age: A Systematic Review
}

\author{
Hyehyung Shin, ${ }^{1}$ Lynn B. Panton, ${ }^{1}$ Gareth R. Dutton, ${ }^{2}$ and Jasminka Z. Ilich ${ }^{1}$ \\ ${ }^{1}$ Department of Nutrition, Food \& Exercise Sciences, College of Human Sciences, Florida State University, Tallahassee, \\ FL 32306-1493, USA \\ ${ }^{2}$ Department of Medical Humanities \& Social Sciences, College of Medicine Florida State University, Tallahassee, \\ FL 32306-4300, USA
}

Correspondence should be addressed to Jasminka Z. Ilich, jilichernst@fsu.edu

Received 22 August 2010; Accepted 14 December 2010

Academic Editor: Iris Reuter

Copyright (c) 2011 Hyehyung Shin et al. This is an open access article distributed under the Creative Commons Attribution License, which permits unrestricted use, distribution, and reproduction in any medium, provided the original work is properly cited.

\begin{abstract}
The purpose of this review was to examine the relationship between physical performance and body composition measurements, including fat/muscle mass and bone mineral density (BMD) in individuals $\geq 60$ years of age. Various measurements used to assess body composition, BMD, and physical performance (PP) were discussed as well. Medline/PubMed, CINAHL, and SCIE were used to identify articles. After limiting the search for age and kind of physical performance measures, 33 articles were evaluated. Higher fat mass was associated with poorer physical performance while higher muscle mass was a predictor of better physical performance, especially in the lower extremities. Additionally, evidence showed that higher muscle fat infiltration was a determinant of poorer physical performance. BMD was shown to be a good predictor of physical performance although the relationship was stronger in women than in men. Developing standardized methods for PP measurements could help in further investigation and conclusions of its relationship with body composition.
\end{abstract}

\section{Introduction}

The aging process is characterized by gradual declines in physical and cognitive functions. Some elderly become frail and experience a decline in muscle mass and strength, as well as functional disability. Preserving physical performance (PP) could secure independent living, which for older adults permits the satisfaction of being self-sustained and drastically reduces economic/health care costs. Studies have shown that functional disability increases dependence [1], risk of falls, cardiovascular diseases, mortality $[2,3]$, and overall health status of older individuals $[1,4]$. In the United States, more than half of individuals $>70$ years have one or more functional disabilities and only one third of noninstitutionalized individuals $>80$ years are free of functional disabilities [5].

It is unclear whether the decline in PP can be explained by changes in body composition: fat mass, muscle mass, and/or bone mass (i.e., bone mineral density, BMD). In the older population, the changes in body composition, especially declines in muscle and bone mass, are challenging research topics with regard to PP. Several epidemiological studies have shown inconsistent results examining muscle, fat and/or bone mass predicting PP among older adults [6-10]. Visser et al. [9] reported that higher body fat was associated with functional disability in older Caucasian men and women and Woo et al. showed similar results in older Asian population. Other studies $[11,12]$ found that low fat-free mass is an independent predictor of functional disability. For example, Reid et al. [12] found that older adults with lower skeletal leg muscle mass were at higher risk for mobility disability. In the study with 1051 community dwelling Caucasian men and women, both lowest quartile of fat-free mass and highest quartile of fat mass were independent predictors of functional disability [6]. In addition, PP in older adults measured by handgrip strength was positively associated 
with BMD in various skeletal sites [13, 14], suggesting that there might be positive association between BMD and PP in older adults.

The inconsistent findings regarding the relationship between PP and body composition (fat mass, muscle mass, and BMD) might be due to several reasons: (1) the relationship between muscle mass, fat mass, and/or BMD and PP may be the outcome of interaction between loss of bone and muscle mass [15-17]; (2) the decline of PP may be caused in large part by cognitive decline which is not always assessed; (3)third is the use of different measurements for the assessment of both PP and body composition [18].

The purpose of this review is to examine the relationship among PP and body composition measures of fat mass, muscle mass, and BMD in individuals $\geq 60$ years of age. By examining the literature from clinical studies, several possibilities for explaining the relationship between body composition and PP are explored and discussed. Various measurements used to assess bone and body composition as well as PP measures are also discussed.

\section{Methods}

2.1. Literature Search. Three major electronic databases including Medline/PubMed, Cumulative Index of Nursing, and Allied Health (CINAHL) were used to search relevant literature using the combination of the following keywords: "body composition," "muscle," "body fat," "physical performance," "physical function," "functional performance", and "bone mineral density." Of 334 retrieved articles, those lacking any measured component of body composition/BMD and PP were excluded, leaving 130 articles. Within the body composition term, body fat and muscle mass were considered. The latter term was sometimes referred to as lean mass, fat-free mass, mineral-free lean mass, or skeletal muscle (depending on how it was described in the original article). Therefore, all four terms are used interchangeably in this review. Physical performaance was sometimes referred to as "functionality," "physical function," and/or "functional performance" - all expressions termed as PP in this review. In addition, only the most widely used PP measures, including sit-to-stand, walking speed, one-leg-stance, and handgrip strength, were examined. Only the studies in which subjects were $\geq 60$ years were considered. If the range of age was not specified in the article, only studies where the average age of subjects was greater than 60 years by one standard deviation away from the mean were included. By limiting the search to human subjects aged $\geq 60$ years, 33 articles were chosen and evaluated. Tables 1 and 2 summarize these studies grouped by similar findings.

2.2. Body Composition and PP Assessments. Measurements of body composition and BMD as well as definition of various PP measures and the ways they are assessed are described as follows.

2.2.1. Body Composition and BMD Measurements. There are several ways to evaluate body composition, including anthropometric measures, underwater weighing, skinfold thickness, or by using techniques such as bioelectrical impedance analysis (BIA), dual energy X-ray absorptiometry (DXA), computed tomography (CT), or magnetic resonance imaging (MRI). The anthropometric measurements are the most readily available and inexpensive methods. They include the use of body mass index (BMI, based on height and weight), waist circumference (WC), and waistto-hip ratio (WHR). Since BMI is used for the assessment of overweight/obesity, and WC and WHR are good surrogate measures of abdominal fat [19], these measures are widely used in many studies [20, 21]. Underwater weighing is considered the gold standard for measuring body density and is based on the difference in densities between fat (less dense) and muscle (denser). Skinfold thickness could be easier and quicker to perform; however, they can yield inaccurate results and depend heavily on the skills of the individual who performs them. Because of difficulty and inaccuracies in performing underwater weighing and skinfolds, respectively, especially in the elderly, this review did not include the studies that utilized these two methods for body composition assessment.

Recently, other techniques such as BIA and DXA have become widely used. BIA and/or DXA can estimate/analyze the amount of fat and muscle mass in different body compartments, which gives more detailed information for body composition assessment. Although in some studies [16, 17] DXA produced higher estimates of fat mass compared to the underwater weighing, DXA is more precise than BIA [22], the latter depending heavily on the hydration status of subjects [15]. Other technologies, such as CT and MRI are also used to measure body composition at the subcompartmental level. CT has been widely used to measure muscle attenuation or intramuscular adiposity as a quantitative method to assess muscle quality. However, safety concerns have arisen regarding the use of CT because of the higher radiation and adverse reactions to contrast agents. Unlike CT, MRI does not utilize radiation; however, it has limited use on persons with implants and ancillary clinical devices such as pacemakers and defibrillators. Both CT and MRI are more expensive, not readily available and used less in research settings.

For the measurement of BMD, DXA is the method of choice due to its reliability and the only one used to diagnose osteoporosis [29]. In addition, quantitative ultrasound bone densitometry (QUS) is also widely used to assess bone health because of its low cost, easy transport, and radiation-free. Although studies have shown good predictability of fracture risk with QUS, the measurement is limited to the calcaneous region of bone, and it has been shown to be less precise than DXA. Overall, the studies reviewed herein utilized BIA, DXA, and CT to analyze body composition, and QUS and DXA for bone mineral density.

2.2.2. Physical Performance Measures and Assessment. To assess PP such as agility, mobility, and balance, several tasks have been developed including timed chair sit-to-stand (STS), normal/brisk walking, timed up-and-go test (TUGT), 
TABLE 1: Summary of studies examining the relationship between physical performance (PP) and body composition.

\begin{tabular}{|c|c|c|c|c|c|c|c|c|}
\hline $\begin{array}{l}\text { Author, } \\
\text { year }\end{array}$ & Participants & $\begin{array}{l}N \text { (\% of } \\
\text { women) }\end{array}$ & $\begin{array}{l}\text { Age (year) } \\
\text { Mean (SD) }\end{array}$ & $\begin{array}{l}\mathrm{BMI}^{\mathrm{a}} \\
\text { Mean (SD) }\end{array}$ & $\begin{array}{l}\text { Body } \\
\text { composition }\end{array}$ & $\begin{array}{l}\text { Physical } \\
\text { performance } \\
\text { measure }\end{array}$ & Fat mass & Muscle mass \\
\hline \multicolumn{9}{|c|}{ Fat mass and physical functionality } \\
\hline $\begin{array}{l}\text { Bohannon } \\
\text { et al. } 2005\end{array}$ & $\begin{array}{l}\text { Community } \\
\text { dwelling women }\end{array}$ & $\begin{array}{l}104 \\
(100)\end{array}$ & $74.9(7.5)$ & $28.1(6.7)$ & $\begin{array}{l}\text { BMI, WC, } \\
\text { WHR }\end{array}$ & $\begin{array}{l}\text { Timed STS } \\
\text { Unilateral } \\
\text { standing (OLS) } \\
\text { 25-ft walk }\end{array}$ & $\begin{array}{l}\text { Negative } \\
(r=0.221 \text { to } \\
0.397 \text { for STS } \\
\text { and } 25-\mathrm{FW} ; \\
r=-0.231 \text { to } \\
-0.233 \text { for OLS })\end{array}$ & N/A \\
\hline $\begin{array}{l}\text { Sharkey } \\
\text { and Branch, } \\
2004\end{array}$ & $\begin{array}{l}\text { Nutrition and } \\
\text { Function Study } \\
\text { (NAFS) }\end{array}$ & $\begin{array}{l}345 \\
(81)\end{array}$ & $78.2(8.4)$ & $\begin{array}{l}34.5 \% \text { are } \\
\text { obese } \\
(\mathrm{BMI} \geq 30)\end{array}$ & BMI & $\begin{array}{l}\text { SLEPS (OLS, } \\
\text { walking speed, } \\
\text { STS) }\end{array}$ & Negative & N/A \\
\hline $\begin{array}{l}\text { Jankowski } \\
\text { et al. } 2008\end{array}$ & $\begin{array}{l}\text { Women and } \\
\text { men with low } \\
\text { serum DHEA }\end{array}$ & $\begin{array}{l}109 \\
(50)\end{array}$ & $69(7)$ & $27.2(4.8)$ & BMI, DXA & CS-PFP & $\begin{array}{l}\text { Negative }(\mathrm{BMI}, \\
r^{2}=0.50 ; \text { Fat } \\
\text { index }\left(\mathrm{kg} / \mathrm{m}^{2}\right) \\
\left.r^{2}=0.52\right)\end{array}$ & NS \\
\hline $\begin{array}{l}\text { Bouchard } \\
\text { et al. } 2007\end{array}$ & $\begin{array}{l}\text { NuAge } \\
\text { (Canada) }\end{array}$ & $\begin{array}{l}904 \\
(48)\end{array}$ & $74(4.1)$ & $27.9(4.6)$ & DXA & $\begin{array}{l}\text { Walking speed, } \\
\text { Balance (OLS) }\end{array}$ & $\begin{array}{l}\text { Negative } \\
\left(r^{2}=0.48 \text { with }\right. \\
\text { OLS; } 0.57 \text { with } \\
\text { WS })\end{array}$ & NS \\
\hline
\end{tabular}

Body fat, muscle mass and PP

\begin{tabular}{|c|c|c|c|c|c|c|c|c|}
\hline $\begin{array}{l}\text { Woo } \\
\text { et al. } 2007\end{array}$ & $\begin{array}{l}\text { Community } \\
\text { dwelling elderly } \\
\text { living in Hong } \\
\text { Kong }\end{array}$ & $\begin{array}{l}4000 \\
(50)\end{array}$ & $65+$ & $23.7(3.3)$ & BMI, DXA & $\begin{array}{l}\text { Walking speed, } \\
\text { HGS }\end{array}$ & $\begin{array}{l}\text { U-shape with } \\
\text { BMI Negative } \\
\text { with fat mass }\end{array}$ & $\begin{array}{l}\text { Positive (ASM with } \\
\text { HGS) }\end{array}$ \\
\hline $\begin{array}{l}\text { Estrada } \\
\text { et al. } 2007\end{array}$ & $\begin{array}{l}\text { Women } \\
\text { receiving } \\
\text { estrogen for } \\
\text { osteoporosis for } \\
2 \text { years }\end{array}$ & $\begin{array}{l}189 \\
(100)\end{array}$ & $67.5(4.8)$ & $24.4(3.0)$ & DXA & $\begin{array}{l}\text { Walking speed, } \\
\text { OLS, STS, HGS }\end{array}$ & $\begin{array}{l}\text { Negative (AFMI; } \\
r=-0.30 \text { to } \\
-0.016 \text {, except } \\
\text { HGS) }\end{array}$ & $\begin{array}{l}\text { Positive (ASM of } \\
\text { lower limb; } \\
r=0.18 \text { with WS; } \\
0.21 \text { with HGS) }\end{array}$ \\
\hline $\begin{array}{l}\text { Valentine } \\
\text { et al. } 2009\end{array}$ & $\begin{array}{l}\text { Community } \\
\text { dwelling elderly }\end{array}$ & $\begin{array}{l}134 \\
(63)\end{array}$ & $\begin{array}{l}69.6(5.4 \\
\text { F) } 70.3 \\
(4.7, M)\end{array}$ & $28.3(4.6)$ & DXA & $\begin{array}{l}\text { OLS, TUGT, } \\
\text { walking speed }\end{array}$ & $\begin{array}{l}\text { Negative } \\
(r=0.29 \text { to } \\
0.38)\end{array}$ & $\begin{array}{l}\text { Positive (leg to } \\
\text { total body ratio; } \\
r=-0.29 \text { with } \\
\text { TUGT, }-0.041 \\
\text { with WS in women } \\
\text { only) }\end{array}$ \\
\hline $\begin{array}{l}\text { Visser } \\
\text { et al. } 2000\end{array}$ & $\begin{array}{l}\text { Longitudinal } \\
\text { Aging Study } \\
\text { Amsterdam }\end{array}$ & $\begin{array}{l}449 \\
(52)\end{array}$ & $\begin{array}{l}75(\mathrm{~F}) \\
75.8(\mathrm{M})\end{array}$ & $26.9(4.2)$ & DXA & WS, STS & N/A & $\begin{array}{l}\text { Positive } \\
(r=0.202)\end{array}$ \\
\hline $\begin{array}{l}\text { Reid } \\
\text { et al. } 2008\end{array}$ & $\begin{array}{l}\text { Mobility limited } \\
\text { community } \\
\text { dwelling elderly } \\
\text { living in Boston }\end{array}$ & $57(54)$ & $74.2(7)$ & $28.9(6.0)$ & DXA & $\begin{array}{l}\text { SPPB score less } \\
\text { than } 7\end{array}$ & NS & $\begin{array}{l}\text { Positive (with } 1 \mathrm{~kg} \\
\text { increase in muscle } \\
\text { mass, OR }=0.47 \text {, } \\
\text { CI }[0.25,0.91] \text { ) }\end{array}$ \\
\hline $\begin{array}{l}\text { Newman } \\
\text { et al. } 2003\end{array}$ & $\begin{array}{l}\text { Health ABC } \\
\text { study }\end{array}$ & $\begin{array}{l}2984 \\
(52)\end{array}$ & $73.6(2.9)$ & $27.4(4.8)$ & DXA & $\begin{array}{l}\text { EPESE score } \\
\text { less than } 10\end{array}$ & N/A & $\begin{array}{l}\text { Positive } \\
\text { (Sarcopenia, } \\
\text { OR = 1.5, CI [1.1, } \\
2.1] \text { ) }\end{array}$ \\
\hline
\end{tabular}


TABle 1: Continued.

\begin{tabular}{|c|c|c|c|c|c|c|c|c|}
\hline $\begin{array}{l}\text { Author, } \\
\text { year }\end{array}$ & Participants & $\begin{array}{l}N(\% \text { of } \\
\text { women })\end{array}$ & $\begin{array}{l}\text { Age (year) } \\
\text { Mean (SD) }\end{array}$ & $\begin{array}{l}\text { BMI }^{\mathrm{a}} \\
\text { Mean (SD) }\end{array}$ & $\begin{array}{l}\text { Body } \\
\text { composition }\end{array}$ & $\begin{array}{l}\text { Physical } \\
\text { performance } \\
\text { measure }\end{array}$ & Fat mass & Muscle mass \\
\hline \multicolumn{9}{|c|}{ Muscle mass and handgrip strength } \\
\hline $\begin{array}{l}\text { Visser } \\
\text { et al. } 1998\end{array}$ & $\begin{array}{l}\text { Framingham } \\
\text { Heart Study } \\
\text { Cohort }\end{array}$ & $\begin{array}{l}753 \\
(63)\end{array}$ & $78.2(0.3)$ & $26.8(0.3)$ & $\begin{array}{l}\text { DXA, WHR, } \\
\text { WC }\end{array}$ & HGS & N/A & Positive \\
\hline $\begin{array}{l}\text { Payette } \\
\text { et al. } 1998\end{array}$ & $\begin{array}{l}\text { Quebec elderly } \\
\text { women }\end{array}$ & $\begin{array}{l}30 \\
(100)\end{array}$ & $81.5(7.0)$ & $26.0(4.7)$ & BIA, BMI & HGS, TUGT & N/A & $\begin{array}{l}\text { Positive ( } r=0.62 \text {, } \\
\text { HGS) NS (with } \\
\text { TUGT) }\end{array}$ \\
\hline $\begin{array}{l}\text { Lee et al. } \\
2007\end{array}$ & $\begin{array}{l}\text { Community } \\
\text { dwelling elderly } \\
\text { living in Hong } \\
\text { Kong }\end{array}$ & $\begin{array}{l}4000 \\
(50)\end{array}$ & $72.5(5.2)$ & N/A & DXA & $\begin{array}{l}\text { STS, HGS, } \\
\text { Walking speed }\end{array}$ & N/A & $\begin{array}{l}\text { Positive (ASMI } \\
\text { with HGS; walking } \\
\text { speed and STS in } \\
\text { women only) }\end{array}$ \\
\hline $\begin{array}{l}\text { Rolland } \\
\text { et al. } 2003\end{array}$ & EPIDOS study & $\begin{array}{l}1458 \\
(100) \\
\end{array}$ & $70+$ & $25.1(3.9)$ & DXA & HGS & N/A & $\begin{array}{l}\text { Positive (ASM, } \\
r=0.24)\end{array}$ \\
\hline $\begin{array}{l}\text { Rolland } \\
\text { et al. } 2004\end{array}$ & EPIDOS study & $\begin{array}{l}1458 \\
(100)\end{array}$ & $70+$ & $25.1(3.9)$ & DXA & HGS & N/A & $\begin{array}{l}\text { Positive in BMI less } \\
\text { than } 29\end{array}$ \\
\hline $\begin{array}{l}\text { Pedersen } \\
\text { et al. } 2002\end{array}$ & $\begin{array}{l}\text { Dannish } \\
\text { (Glostrup) } \\
\text { community } \\
\text { dwelling elderly }\end{array}$ & $\begin{array}{l}226 \\
(47)\end{array}$ & 80 & $26.6(4.5)$ & BMI, BIA & HGS, PPT & NS & $\begin{array}{l}\text { Positive (HGS, } \\
r=0.40 \text { for men; } \\
0.22 \text { for women) }\end{array}$ \\
\hline $\begin{array}{l}\text { Taaffe } \\
\text { et al. } 2001\end{array}$ & $\begin{array}{l}\text { Health ABC } \\
\text { Study }\end{array}$ & $\begin{array}{l}2619 \\
(51)\end{array}$ & $73.6(2.9)$ & $27.1(4.5)$ & DXA & HGS & $\begin{array}{l}\text { No association } \\
(r=0.07 \text { with } \\
\text { upper extremity; } \\
0.08 \text { with total })\end{array}$ & $\begin{array}{l}\text { Positive ( } r=.39 \\
\text { with upper } \\
\text { extremity; } .32 \text { with } \\
\text { total) }\end{array}$ \\
\hline \multicolumn{9}{|c|}{ Muscle quality and PP } \\
\hline $\begin{array}{l}\text { Misic } \\
\text { et al. } 2007\end{array}$ & $\begin{array}{l}\text { Community } \\
\text { dwelling elderly }\end{array}$ & $\begin{array}{l}55 \\
(36 / 19)\end{array}$ & $69.3(5.5)$ & $28.7(4.5)$ & DXA & $\begin{array}{l}\text { Berg balance } \\
\text { scale, Walking } \\
\text { speed }\end{array}$ & $\begin{array}{l}\text { Negative } \\
(r=-0.35 \text { with } \\
\text { BBS; }-0.33 \text { with } \\
\text { WS })\end{array}$ & $\begin{array}{l}\text { NS (Lower } \\
\text { extremity muscle } \\
\text { mass) }\end{array}$ \\
\hline $\begin{array}{l}\text { Sipila and } \\
\text { Suominen, } \\
1994\end{array}$ & $\begin{array}{l}\text { Finnish former } \\
\text { athletes }(A) \text { and } \\
\text { controls }(C)\end{array}$ & $\begin{array}{l}33 \\
(100)\end{array}$ & $\begin{array}{l}73.7(5.6 \\
\text { A) } 73.6 \\
(2.9, C)\end{array}$ & N/A & BIA, CT & Walking speed & $\begin{array}{l}\text { Negative } \\
(r=-0.48(\mathrm{~A}) \\
-0.66(\mathrm{C}))\end{array}$ & NS (muscle index) \\
\hline $\begin{array}{l}\text { Visser } \\
\text { et al. } 2002\end{array}$ & $\begin{array}{l}\text { Health ABC } \\
\text { study }\end{array}$ & $\begin{array}{l}2979 \\
(52)\end{array}$ & $70-79$ & $27.3(4.6)$ & $\begin{array}{l}\text { CT } \\
\text { (Midthigh) }\end{array}$ & $\begin{array}{l}\text { LEP (walking } \\
\text { speed and STS) }\end{array}$ & $\begin{array}{l}\text { Negative (fat } \\
\text { infiltration) }\end{array}$ & Positive \\
\hline $\begin{array}{l}\text { Hicks } \\
\text { et al. } 2005\end{array}$ & $\begin{array}{l}\text { Health ABC } \\
\text { study (Pittsburg } \\
\text { site only) }\end{array}$ & $\begin{array}{l}1527 \\
(48)\end{array}$ & $70-79$ & $27 \%$ & $\begin{array}{l}\text { CT } \\
\text { (Midthigh } \\
\text { and trunk) }\end{array}$ & $\begin{array}{l}\text { Health ABC } \\
\text { PPB (STS, } \\
\text { OLS, walking } \\
\text { speed) }\end{array}$ & $\begin{array}{l}\text { Negative (fat } \\
\text { infiltration) }\end{array}$ & NS \\
\hline
\end{tabular}

a If the mean was not specified, number indicates \% of BMI greater than 30; SD: standard deviation; STS: sit-to-stand; OLS: one-leg-stance; HGS: handgrip strength; ASM: appendicular skeletal muscle mass; N/A: not available, no data; NS: not significant.

one-leg stance (OLS), and handgrip strength measured with the hand dynamometer. The items including STS, TUGT, and OLS are appropriate to test lower extremity performance but they have to be used with caution in older adults due to possibilities of falls and injuries. Another problem with using these tasks is that many of them have a "ceiling" or "floor" effect. That is, depending on the subject's ability to perform the given task, the subject may max out or may be too weak or frail to be able to perform the task. At the same time, the test needs to be simple and precise. To prevent these problems, different instruments and procedures have been developed and validated to evaluate physical function in older adults. Table 3 presents the instruments and the respective tests for functional performance. For example, the continuous-scale physical-functional-performance (CSPFP) test or items within the CS-PFP have been widely used to measure the physiological capacity of the elderly or individuals with chronic diseases $[28,30,31]$. 
TABLE 2: Summary of studies of the relationship between physical performance (PP) and bone mineral density (BMD).

\begin{tabular}{|c|c|c|c|c|c|c|c|c|}
\hline $\begin{array}{l}\text { Author, } \\
\text { year }\end{array}$ & Participants & $\begin{array}{l}N(\% \text { of } \\
\text { women })\end{array}$ & $\begin{array}{l}\text { Age (years, } \\
\text { Mean } \\
(\mathrm{SD}))\end{array}$ & $\begin{array}{l}\text { Weight } \\
(\mathrm{kg})^{\mathrm{a}} \\
\text { Mean (SD) }\end{array}$ & $\begin{array}{l}\text { Height } \\
(\mathrm{cm})^{\mathrm{a}} \\
\text { Mean }(\mathrm{SD})\end{array}$ & BMD measure ${ }^{\mathrm{b}}$ & PP measures & Findings \\
\hline $\begin{array}{l}\text { Madsen } \\
\text { et al. } 2000\end{array}$ & $\begin{array}{l}\text { Community } \\
\text { dwelling elderly }\end{array}$ & $\begin{array}{l}47 \\
(100)\end{array}$ & $80.3(7.0)$ & $60.0(11.3)$ & $156(6)$ & $\begin{array}{l}\text { Leg, lumbar } \\
\text { spine }\end{array}$ & Walking speed & NS \\
\hline $\begin{array}{l}\text { Foley } \\
\text { et al. } 1999\end{array}$ & $\begin{array}{l}\text { Community } \\
\text { dwelling elderly }\end{array}$ & $\begin{array}{l}104 \\
(70)\end{array}$ & $\begin{array}{l}71.0(5.3 \\
\text { F) } 72.4 \\
(4.0, \mathrm{M})\end{array}$ & $71.7(15.8)$ & $160.7(4.6)$ & Femur & HGS & Weak $\left(r^{2}=0.06\right)$ \\
\hline $\begin{array}{l}\text { Cauley } \\
\text { et al. } 2005\end{array}$ & $\begin{array}{l}\text { The Osteoporotic } \\
\text { Fractures in Men } \\
\text { Study (MrOS) }\end{array}$ & $\begin{array}{l}5995 \\
(0)\end{array}$ & $73.7(5.9)$ & $83.1(13.3)$ & $174.1(6.8)$ & $\begin{array}{l}\text { Femur and } \\
\text { lumbar }\end{array}$ & $\begin{array}{l}\text { Walking speed, } \\
\text { STS, and HGS }\end{array}$ & $\begin{array}{l}\text { Positive (STS and } \\
\text { HGS)NS (Walking } \\
\text { speed) }\end{array}$ \\
\hline $\begin{array}{l}\text { Tang } \\
\text { et al. } 2007\end{array}$ & $\begin{array}{l}\text { Elderly living in } \\
\text { veterans' home in } \\
\text { Taiwan }\end{array}$ & $368(0)$ & $78.8(4.1)$ & $62.9(10.4)$ & $162.6(5.9)$ & $\begin{array}{l}\text { Calcaneus bone } \\
\text { with Soundscan }\end{array}$ & $\begin{array}{l}\text { 6-min walking } \\
\text { distance }\end{array}$ & $\begin{array}{l}\text { Positively graded } \\
\text { association across } \\
\text { the quartile }\end{array}$ \\
\hline $\begin{array}{l}\text { Sun } \\
\text { et al. } 2009\end{array}$ & $\begin{array}{l}\text { Community- } \\
\text { dwelling elderly } \\
\text { women in Japan } \\
(200)\end{array}$ & $\begin{array}{l}200 \\
(100)\end{array}$ & $65+$ & $23.1(3.2$ & 2, BMI) & QUS & $\begin{array}{l}\text { Usual and } \\
\text { maximum } \\
\text { walking speed }\end{array}$ & $\begin{array}{l}\text { Positive ( } r=0.24 \\
\text { with usual walking } \\
\text { speed and } .26 \text { with } \\
\text { maximum walking } \\
\text { speed) }\end{array}$ \\
\hline $\begin{array}{l}\text { Taaffe } \\
\text { et al. } 2003\end{array}$ & Health ABC study & $\begin{array}{l}3041 \\
(52)\end{array}$ & $74.2(7)$ & $28.9(6$, & , BMI) & $\begin{array}{l}\text { Femoral neck } \\
\text { and trochanter }\end{array}$ & $\begin{array}{l}\text { STS, 6-m } \\
\text { walking speed } \\
\text { and OLS }\end{array}$ & $\begin{array}{l}\text { Positive (graded } \\
\text { association) }\end{array}$ \\
\hline $\begin{array}{l}\text { Lindsey } \\
\text { et al. } 2005\end{array}$ & $\begin{array}{l}\text { Healthy } \\
\text { postmenopausal } \\
\text { women }\end{array}$ & $\begin{array}{l}116 \\
(100)\end{array}$ & $68.3(6.8)$ & $67.9 \pm 11.0$ & $161.8(6.5)$ & $\begin{array}{l}\text { Femoral neck, } \\
\text { hip and total }\end{array}$ & $\begin{array}{l}\text { normal and brisk } \\
8 \mathrm{~m} \text { walking } \\
\text { speed, normal } \\
\text { step length, brisk } \\
\text { step length, OLS, } \\
\text { STS, and HGS }\end{array}$ & $\begin{array}{l}\text { Positive ( } r^{2} \text { ranged } \\
\text { from } 0.19 \text { to } 0.38 \text { ) }\end{array}$ \\
\hline
\end{tabular}

Positive $(r=0.26$, 0.17 and 0.15 with

\begin{tabular}{|c|c|}
\hline $\begin{array}{l}\text { Taaffe } \\
\text { t al. } 2001\end{array}$ & $\begin{array}{l}\text { Health ABC } \\
\text { Study }\end{array}$ \\
\hline
\end{tabular}
upper limb BMD, lower limb BMD and total BMD resp.)

\begin{tabular}{|c|c|c|c|c|c|c|c|c|}
\hline $\begin{array}{l}\text { Orwoll } \\
\text { et al. } 1996\end{array}$ & $\begin{array}{l}\text { Study of } \\
\text { Osteoporotic } \\
\text { Fractures }\end{array}$ & $\begin{array}{l}5405 \\
(100)\end{array}$ & $73.8(5.3)$ & $66.4(12.5)$ & $159.2(6.0)$ & $\begin{array}{l}\text { Distal radius and } \\
\text { femoral neck }\end{array}$ & HGS & Positive \\
\hline $\begin{array}{l}\text { Kritz- } \\
\text { Silverstein } \\
\text { and Barrett- } \\
\text { Conner, } \\
1994\end{array}$ & $\begin{array}{l}\text { Postmenopausal } \\
\text { Caucasian } \\
\text { women aged } 65 \\
\text { years and older } \\
\text { living in Southern } \\
\text { California }\end{array}$ & $\begin{array}{l}649 \\
(100)\end{array}$ & $65+$ & N/A & N/A & $\begin{array}{l}\text { Single-photon } \\
\text { absorptiometry } \\
\text { for upper limb } \\
\text { and DXA for } \\
\text { lumbar and spine }\end{array}$ & HGS & $\begin{array}{l}\text { Positive } \\
\text { (nondominant } \\
\text { arms; } r^{2} \text { ranged } \\
\text { from } 0.15 \text { to } 0.28 \text { ) }\end{array}$ \\
\hline $\begin{array}{l}\text { Bauer } \\
\text { et al. } 1993\end{array}$ & $\begin{array}{l}\text { Nonblack women } \\
\text { recruited from } \\
\text { four clinical } \\
\text { centers }\end{array}$ & $\begin{array}{l}9704 \\
(100)\end{array}$ & $71.6(5.3)$ & $67.3(12.6)$ & $159(6.0)$ & $\begin{array}{l}\text { Distal radius } \\
\text { from } \\
\text { Osteoanalyzer }\end{array}$ & HGS & $\begin{array}{l}\text { Positive ( } 5 \mathrm{~kg} \\
\text { increase with } 4.9 \% \\
\text { increase in distal } \\
\text { radius bone mass } \\
(95 \% \mathrm{CI}[4.1,5.6])\end{array}$ \\
\hline
\end{tabular}


TABLE 2: Continued.

\begin{tabular}{|c|c|c|c|c|c|c|c|c|}
\hline $\begin{array}{l}\text { Author, } \\
\text { year }\end{array}$ & Participants & $\begin{array}{l}N(\% \text { of } \\
\text { women })\end{array}$ & $\begin{array}{l}\text { Age (years, } \\
\text { Mean } \\
(\text { SD) })\end{array}$ & $\begin{array}{l}\text { Weight } \\
(\mathrm{kg})^{\mathrm{a}} \\
\text { Mean (SD) }\end{array}$ & $\begin{array}{l}\text { Height } \\
(\mathrm{cm})^{\mathrm{a}} \\
\text { Mean }(\mathrm{SD})\end{array}$ & BMD measure ${ }^{b}$ & PP measures & Findings \\
\hline $\begin{array}{l}\text { Bevier et al. } \\
1989\end{array}$ & $\begin{array}{l}\text { Healthy active } \\
\text { men and women } \\
\text { living in Palo } \\
\text { Alto, California }\end{array}$ & $91(0)$ & $70(0.7)$ & $70.1(1.4)$ & $165.8(1.0)$ & $\begin{array}{l}\text { Radius and } \\
\text { lumbar }\end{array}$ & HGS & $\begin{array}{l}\text { Positive }(r=0.28 \\
\text { to } 0.42)\end{array}$ \\
\hline $\begin{array}{l}\text { Kärkkäinen } \\
\text { et al. } 2009\end{array}$ & $\begin{array}{l}606 \text { Finnish } \\
\text { elderly women }\end{array}$ & $\begin{array}{l}606 \\
(100)\end{array}$ & $68.0(1.8)$ & $28.8(4$. & 7, BMI) & $\begin{array}{l}\text { Hip and lumbar } \\
\text { spine }\end{array}$ & $\begin{array}{l}\text { OLS, HGS, } \\
\text { Walking speed, } \\
\text { STS }\end{array}$ & $\begin{array}{l}\text { Positive (Hip } \\
\text { BMD, } r^{2} \text { ranged } \\
\text { from } 0.16 \text { to } 0.23 \text {; } \\
\text { Lumbar BMD, } \\
r^{2}=0.16, P<.05 \\
\text { with OLS and } \\
\text { HGS only) }\end{array}$ \\
\hline
\end{tabular}

SD: standard deviation; BMD: bone mineral density; M: male; F: female; STS: sit-to-stand; OLS: one-leg-stance; HGS: handgrip strength; N/A: not available, no data; NS: not significant.

${ }^{a}$ If there is no information on weight and height, BMI is noted instead.

${ }^{\mathrm{b}}$ All BMDs were measured by DXA if not otherwise noted.

TABLE 3: Summary of instruments for physical performance (PP) tests.

\begin{tabular}{|c|c|c|c|c|}
\hline Items & Sit-to-stand & Balance & Walking speed & Others \\
\hline $\begin{array}{l}\text { The short physical } \\
\text { performance battery [23] }\end{array}$ & 5 repetition & $\begin{array}{l}\text { Tandem, semitandem, and side-by-side } \\
\text { stands ( } 10 \text { seconds maximum) }\end{array}$ & 4-meter & \\
\hline $\begin{array}{l}\text { The health, aging, and body } \\
\text { composition study Physical } \\
\text { Performance Battery [24] }\end{array}$ & 5 repetition & $\begin{array}{l}\text { Tandem, semitandem, and side-by-side } \\
\text { stands ( } 10 \text { seconds maximum) }\end{array}$ & $\begin{array}{l}\text { 6-meter at usual } \\
\text { walking speed and } \\
6 \text {-meter narrow walk }\end{array}$ & \\
\hline $\begin{array}{l}\text { Summary lower-extremity } \\
\text { performance scores [25] }\end{array}$ & 5 repetition & $\begin{array}{l}\text { Tandem, semi-tandem, and } \\
\text { side-by-side stands ( } 10 \text { seconds } \\
\text { maximum) Timed } 360 \text {-degree turn } \\
\text { (turning in a full circle), one to the } \\
\text { right and one to the left }\end{array}$ & $\begin{array}{l}8 \text {-ft }(\sim 2.4 \text {-meter }) \\
\text { walk }\end{array}$ & \\
\hline $\begin{array}{l}\text { United states Physical } \\
\text { Performance Test }[26,27]\end{array}$ & N/A & Timed 360-degree turn & $\begin{array}{l}\text { Timed 4.8-meter } \\
\text { walking }\end{array}$ & $\begin{array}{l}\text { Writing a sentence, } \\
\text { simulating eating, lifting a } \\
\text { book above shoulder level, } \\
\text { putting on and removing } \\
\text { a lab coat and picking up } \\
\text { a coin from the floor }\end{array}$ \\
\hline
\end{tabular}

Continuous-scale physicalfunctional-performance test [28]

5 domains: upper body strength, upper body flexibility, lower body strength, balance and coordination, and endurance

References indicate the validation studies.

N/A: not available.

Another instrument, the United States Physical Performance Test (US PPT) $[26,32]$, is a functional ability test with seven or nine functional items. The test items simulate daily living activities and measure the time taken to perform them. Each item on a test is scored from 0 to 4 according to time required to perform, which yields a sum score ranging from 0 to $28[1,33]$.

Several test instruments for lower extremity performance are also available. The Short Physical Performance Battery (SPPB) [23] is focused on measuring lower extremity physical function. This tool was developed from the Iowa Established Populations for Epidemiologic Studies of the Elderly study and contains three categories: a balance test, a 4-meter walking speed test, and a timed chair sit-to-stand test for 5 repetitions. Each category has a 4-point maximum, with a total of 12 points possible with a higher score indicating less physical impairment $[12,34]$. The Health, Aging, and Body Composition study (Health $\mathrm{ABC}$ ) also developed the Health ABC Physical Performance Battery (PPB) to measure physical function in the elderly, which is modified from the lower extremity performance portion of the Established Populations for Epidemiologic Studies of the Elderly test [24]. The Summary Lower-Extremity Performance Scores (SLEPSs) introduced by Sharkey et al. [35] also emphasize examining lower-extremity performance. It has four categories including static and dynamic balance, usual walking 
speed, and repeated chair sit-to-stand. The total possible score is 14 , with higher score indicating better performance. It has been reported that the score distribution is highly skewed; thus it is recommended to construct three categories according to the total score as follows: worst performance (SLEPS: 0-4), intermediate performance (SLEPS: 5-9), and best performance (SLEPS: 10-14). Finally, the Berg Balance Scale (BBS) is especially designed to measure balance function in older adults and includes 14 items to measure dynamics of balance. Items are scored ranging from 0 (worst) to 4 (best), with a maximum attainable score of 56 .

Handgrip strength has also been widely used in many studies [9-11, 13, 14, 36-48]. It primarily measures upper body appendicular muscle strength and is a good predictor of functional disability. Factors associated with muscle weakness measured by handgrip strength include decreased physical activity, lower body weight, poor nutritional status, and number of chronic diseases and medication use [42, 49-56]. Besides the functional disability, poor handgrip strength also predicts 5-year mortality in specific popula tions [57-60]. Thus, handgrip strength has frequently been used as a marker for overall muscle strength and health status for the elderly.

\section{Results}

\subsection{Body Composition and Functionality}

3.1.1. Overweight/Obesity and Functionality. Results from most studies [10, 38, 39, 61-64] indicate a negative relationship between fat mass and PP in older adults. Bohannon et al. [65] examined the relationship between adiposity and PP in 104 community-dwelling elderly (aged 60-90 years) women in Connecticut. STS, OLS, and a 25 -foot walk were timed and used to test PP. In this study, PP had a significant negative association with anthropometries, showing that PP decreased as the adiposity measured by BMI, WC, and WHR increased. Sharkey and Branch [63] examined the relationship between SLEPS and BMI in The Nutrition and Function Study population including both men and women aged 78.2 \pm 8.4 years. Based on their PP scores, subjects were divided into the following groups: worst performance (SLEPS 0-4), intermediate performance (SLEPS 5-9), and best performance (SLEPS 10-14). Obese individuals were two times more likely to be in the lower SLEPS performance (SLEPS 5-9) category than nonobese individuals after controlling for chronic health conditions, depression, and demographic characteristics (odds ratio $(\mathrm{OR})=1.99,(95 \% \mathrm{CI}=0.90,4.42) ; P<.05)$.

Interesting results were observed in a study with 4000 community-dwelling adults 65 years and older in Hong Kong [10], showing a U-shaped (quadratic) relationship between $\mathrm{BMI}$ and PP where lower and upper extremity performances were assessed by measuring walking speed from a 6-meterwalking test and handgrip strength, respectively. As a result, the overweight group (defined by BMI 23 to 24.9 for Asian population) showed the highest handgrip strength, while both the underweight $(\mathrm{BMI}<18.5)$ and obese II $(\mathrm{BMI}>30)$ groups showed lower handgrip strength. Similar trends were seen in walking performance. The normal-weight group (BMI 18.5 to 22.9) needed a shorter time for a 6-meter walking compared to other BMI groups. Since both low or high fat mass increases the risk of mortality in the elderly, this quadratic trend emphasizes the influence of fat mass on functional limitation and suggests that underweight or overweight could be detrimental for PP in older adults.

Due to the limitation in using BMI as an assessment for body fat, other studies $[10,61,62]$ have utilized DXA to quantify fat or muscle mass or have developed indices such as calculated fat index (fat mass $(\mathrm{kg}) /$ height $(\mathrm{m})^{2}$ ) and appendicular skeletal muscle index (ASMI, appendicular muscle mass $(\mathrm{kg}) /$ height $\left.(\mathrm{m})^{2}\right)$ to investigate different compartments of body composition. Considering both body fat and muscle mass, some studies support that adiposity/obesity but not muscle mass was a stronger determinant of PP in older adults. Jankowski et al. [62] examined fat and muscle mass by DXA and PP by the CS-PFP test in 109 community-dwelling healthy women and men aged $69 \pm 7$ years. After adjustment for age, the fat index showed a negative relationship with the CS-PFP test score $\left(r^{2}=0.52, P<.001\right)$. In another model controlled for age and sex, BMI was a negative and significant predictor of CS-PFP test score $\left(r^{2}=0.50\right.$, $P<.001$ ). Similarly, the NuAge (Nutrition as a Determinant of Successful Aging) study with 904 community-dwelling older adults aged 74.0 \pm 4.1 years living in Québec, Canada, showed that a higher percentage of body fat measured by DXA showed shorter timed OLS in both men and women, even after controlling for age, physical activity, and number of self-reported diseases [61]. However, in both of the above studies $[61,62]$, the ASMI was not an explanatory factor of PP.

Overall, the above studies suggest that adiposity is a stronger determinant of PP than muscle mass in older community dwelling adults. Considering that fat mass index is used to normalize skeletal sizes and distinguish between sex differences, which BMI is not [62], the negative relationship between adiposity and PP is well explained when sex difference is accounted for. However, if fat weight is too high (in case of obesity), negative relationship with PP may occur.

Estrada et al. [39] investigated the relationship between both ASMI and appendicular fat mass index and PP in 189 healthy postmenopausal women (aged $67.5 \pm 4.8$ years) receiving estrogen for osteoporosis for 2 years. Fat and muscle mass was measured by DXA and adjusted for height to yield skeletal mass and fat mass indices of both lower and upper extremities. Interestingly, handgrip strength showed positive correlations with both ASMI of total and lower limb $(r=0.21$ and 0.19 , resp., $P<.05)$. However, total and lower extremity fat indices were negatively correlated with all lower extremity PP tests including walking speed, OLS, and STS. Regarding body composition analyzed by DXA, the participants with lowest quartile of fat mass had the strongest handgrip strength and the fastest walking speed after adjusting for age, physical activity, and number of chronic diseases. This shows that each performance on PP test items is correlated with body composition of the particular site used for testing. Therefore, the study supported the association between physical function and appendicular 
fat/muscle mass indicating that the relationship between PP and muscle mass could be site specific.

3.1.2. Muscle Mass and Physical Performance. Several studies $[9,11-13,45-48,56,66]$ have determined that muscle rather than fat mass is significantly positively associated with PP measures. A study with mobility-limited communitydwelling older adults aged $74.2 \pm 7$ years showed that lower leg muscle mass was a significant predictor of $\mathrm{PP}$, as measured by Short Physical Performance Battery (SPPB) [12]. Subjects who were able to gain $1 \mathrm{~kg}$ of muscle mass had $47 \%$ less chance for having severe mobility impairment, as defined by an SPPB score less than 7 (after adjustment for number of medical diagnoses, physical activity level, total hip BMD, total leg muscle mass, and total body fat). Total percentage of body fat was not a significant determinant of SPPB scores.

In addition, gender might be another factor that determines the relationship between muscle mass and PP. A study by Visser et al. [56] examined the Longitudinal Aging Study Amsterdam cohort of 449 men and women aged 65 years and older. Lower extremity muscle mass measured by DXA was positively associated with lower extremity performance, as assessed by walking speed and STS, after adjusting for age and height, in men. The association between lower extremity muscle mass and lower extremity performance in women was positive after adjusting for BMI. A study by Valentine et al. [64] demonstrated that both lower extremity muscle mass (\%) and body fat mass (\%) were positively correlated with faster walking speed in women only. Therefore, not only muscle mass but also \% body fat showed a stronger relationship with PP in women, compared to men. However in sarcopenic subjects, the association appeared to be opposite with reference to sex. Newman et al. [66] examined the PP in people with sarcopenia. In this study, sarcopenia was defined as ASMI at the lowest $20 \%$ of the distribution of study population in both men and women. The results showed that ASMI was the most significant factor correlated with PP measures examined with the Established Populations for Epidemiologic Studies of the Elderly (EPESE) test. After adjusting for age, race, other lifestyle factors, and physical activity, only male subjects who were classified as sarcopenic had 1.5 times more chance of having an EPESE score of less than 10 (CI = 1.1-2.1). Overall, muscle mass was a stronger determinant of lower extremity PP, particularly in men. In women, both higher muscle mass and lower body fat were positively associated with physical function.

3.1.3. Muscle Mass and Handgrip Strength. The positive relationship between muscle mass and PP has been shown more clearly when functionality was measured with handgrip strength $[9-11,13,39,45-48]$. The results from the Framingham Heart Study with 753 men and women aged 7295 years [9] showed that handgrip strength was positively correlated with total body and arm muscle mass measured by DXA after adjustment for age and height (Pearson's $r$ ranged from 0.46 to $0.53, P<.0001$ ). An even stronger relationship was shown in the study by Payette et al. [45] in which 30 community-dwelling elderly women $(81.5 \pm 7$ years) were examined. In this study, muscle mass, determined by BIA, was positively correlated with handgrip strength but not with lower extremity performance measured by TUGT. Similar results were shown with an Asian population living in Hong Kong, where health aspects of 4000 communitydwelling elderly aged $72.5 \pm 5.2$ years were examined [11] The relationship between muscle mass, measured by DXA, and PP measures including STS, handgrip strength, and walking speed was tested. Subjects were divided into groups based on the tertiles of ASMI. After adjusting for age, the highest tertile of ASMI had the strongest handgrip strength in both men and women compared to other groups. Other PP measures using lower extremities were similar across the tertiles of muscle mass in both women and men, suggesting that PP without direct measurement of muscle strength can be more easily explained by higher body fat rather than muscle mass, as supported by studies discussed above.

Additional studies support the notion that handgrip strength is positively correlated with appendicular muscle mass, especially for upper extremities. The EPIDOS (EPIDemiology of OSteoporosis) study with 1,458 French women aged 70 years or older [47] showed positive association between handgrip strength and appendicular muscle mass from four limbs measured by DXA. Rolland et al. [48] also reviewed this relationship by dividing the EPIDOS cohort according to BMI groups. Although there were no significant differences in handgrip strength among BMI groups, the correlation between appendicular skeletal muscle mass measured by DXA and handgrip strength in lean (BMI < 24) and normal-weight to overweight groups $\left(B M I=24-29 \mathrm{~kg} / \mathrm{m}^{2}\right)$ was significantly positive $(P<.001)$; however, the relationship became weaker (although still significant) in the overweight-obese group (BMI $>29 \mathrm{~kg} / \mathrm{m}^{2}$, $P<.05)$. Similarly, Pedersen et al. [46] measured muscle strength including handgrip strength, United States Physical Performance Test (US PPT), and body composition using BIA in 226 older men and women between 70 and 75 years old living in Copenhagen, Denmark. The results showed that the muscle mass measured by BIA was positively correlated with handgrip strength in both men and women. Although the results showed a tendency for the group with BMI < $24 \mathrm{~kg} / \mathrm{m}^{2}$ to have the highest handgrip strength compared to other BMI groups, this tendency was not observed with US PPT. Body fat (\%), which showed a strong correlation with BMI, was also not correlated with handgrip strength, indicating that only muscle mass was the explanatory factor for handgrip strength.

Studies also showed that there is site-specific relationship between handgrip strength and muscle mass, especially with upper extremity muscle mass. Taaffe et al. [13] examined the correlation between the handgrip strength and muscle or fat mass in 2,619 community dwelling elderly participating in the Health $\mathrm{ABC}$ study. It was found that upper extremity muscle mass had the strongest relationship with handgrip strength $(r=0.39)$, followed by total body muscle mass $(r=0.32, P<.001)$. Total body fat and upper extremity fat mass showed no association with handgrip strength. It seems that although handgrip strength has been widely used 
to measure general health status and functional ability in the older adults, handgrip strength is more likely to represent upper extremity muscle mass, rather than muscle or fat mass in the total body.

3.1.4. Muscle Quality and Physical Performance. Misic et al. [67] examined balance with the Berg balance test and walking speed in 55 older adults aged $69.3 \pm 5.5$ years. After comparing with total body fat mass and lower extremity muscle mass measured by DXA, the Berg balance test score and walking speed were negatively correlated with total body fat mass but not lower extremity muscle mass $(P<.05)$. However, they found that the most significant predictor for gait was muscle quality, explaining $29-42 \%$ of the variance. Sipila and Suominen [68] compared former female athletes $(n=19)$ and controls $(n=14)$ aged 66 to 85 years living in Finland to examine the relationship between walking speed and muscle and body composition measured by BIA and CT. Interestingly, walking speed was the only parameter that was significantly correlated with the relative proportion of fat in both groups $(r=-0.48$ and -0.66 for athletes and controls, resp., $P<.05)$. The correlation between muscle index measured by CT and walking speed was not different for athletes and controls.

Composition of muscle has also been explored to measure muscle quality and investigate the relationship with PP in several studies. Higher muscle attenuation expressed as lower fat infiltration (less fat deposited within the muscle) measured by CT is often used as an indicator of better muscle quality. The researchers demonstrated that fat infiltration in muscle as a measure of muscle quality rather than muscle mass was a better predictor of muscle performance $[69,70]$. Visser et al. [69] examined the composition of muscle using $\mathrm{CT}$ and its relationship to lower extremity performance score with the Health $\mathrm{ABC}$ cohort, including 2,979 participants aged 70 to 79 years. Among the Health $A B C$ physical performance battery items, timed chair sit-to-stand test and walking speed were used to test lower extremity performance; each item is scored according to the quartiles of the Health $\mathrm{ABC}$ cohort ( 0 for the last quartile, 4 for the first quartile), less than 4 indicating poor lower extremity performance (LEP). They showed that both higher muscle mass and low fat infiltration as measured by DXA and CT, respectively, were associated with greater lower extremity performance. In other words, the participants who were in the highest tertile of muscle mass or the highest muscle attenuation (lowest fat filtration) had the greatest LEP test scores. In another study using only the Pittsburgh site of the Health $\mathrm{ABC}$ cohort consisting of 1,527 adults aged 70 to 79 years [70], higher fat infiltration in trunk muscle measured by CT was associated with lower test scores on lower extremity performance tests, including repeated chair sit-to-stand, OLS, and 6-meter walking speed. In this study, trunk and thigh muscle area were not significantly associated with PP in this population. However, either higher trunk or thigh fat infiltration was associated with poorer PP in lower extremities.

Although many studies support that muscle mass is a strong predictor of physical function in older adults, it is evident that lower fat infiltration in muscle, as a measure of muscle quality, could be also a good predictor of better PP. Since the role of infiltrated fat in muscle is still unknown, more studies are needed to investigate the effects of fat infiltration on PP.

3.2. Bone Mineral Density and Physical Performance. It is well established that PP is an independent predictor of the risk for falls and fractures [71, 72]. However, the relationship between $\mathrm{PP}$ and $\mathrm{BMD}$ is unclear, with conflicting conclusions from various research studies. With aging, loss of muscle and bone mass has significant implications on both physical function and health $[18,73-75]$.

Some studies support the notion that PP has weak or no association with BMD of various skeletal sites. A study with 47 older women $(80.3 \pm 7.0$ years $)$ who had previous hip fracture showed no association between walking speed and nonfractured leg and lumbar spine BMD [76]. Another study [40] with 104 community dwelling older adults investigated the relationship between femur BMD and handgrip strength, where a positive correlation was only observed in women $(r=0.4, P<.001)$, and not in men $(r=0.27, P=$ .149). There was also a significant correlation between body weight and handgrip strength in women $(r=0.32, P=$ .006); therefore, the latter was allometrically scaled with body weight to reduce the influence from other variables related to body dimension. Linear regression analyses showed that handgrip strength divided by body weight only explained $6 \%$ of variation in femur BMD, which was again shown only in the women. The Osteoporotic Fractures in Men Study [14] including 5,995 men aged $73.7 \pm 5.9$ years showed that only handgrip strength had a positive association with femoral and lumbar BMD measured by DXA. Accordingly, one standard deviation increase in handgrip strength $(8.2 \mathrm{~kg})$ showed significant increases in femoral and lumbar BMD $(\mathrm{OR}=1.75[1.3,2.2](\%)$ and $1.74[1.3,2.2](\%)$, resp.) after adjustment for age, but these associations disappeared after adjusting for both age and weight $(\mathrm{OR}=$ $0.73[0.3,1.2](\%)$ and $1.05[0.6,1.5](\%)$, resp.). On the other hand, slower STS (3.3 seconds) was not associated with lower femoral and lumbar BMD (OR $=-0.05[-0.4,-0.5](\%)$, $-0.06[-0.5,-0.4](\%)$, resp.) in age-adjusted models, which appeared to be significant after adjusting for both age and weight $(-1.06[-1.5,-0.7](\%),-0.85[-1.3,-0.4](\%)$, resp.). Walking speed however showed no association with BMD.

Conversely, other studies have shown positive associations between BMD of various skeletal sites and lower extremity PP measures [41, 77, 78]. Results of the study in 368 older men aged $78.8 \pm 4.1$ years living in a veterans' home in Taiwan [78] found that the calcaneus bone mass measured by Soundscan (quantitative ultrasound) expressed as broadband ultrasound attenuation was positively correlated with walking speed measured by a 6-minute walking distance. After adjusting for BMI, waist circumference, and hemoglobin level as a marker of nutritional adequacy and status, mean broadband ultrasound attenuation (BUA) values were significantly different among the groups, classified 
according to the quartiles of 6-minute walking distance, showing that the lowest quartile had the shortest 6-minute walking distance. Similar trends were shown in the study with female subjects in Japan [77]. In this study which was conducted with 200 Japanese women 65 years and older, the relationship between walking parameters and bone health as measured by quantitative ultrasound bone densitometer expressed as stiffness index was examined. The results showed that higher stiffness index (SI) was positively correlated with faster usual and maximum walking speed. In multiple regression analysis with BMI, handgrip strength, and walking parameters, maximum walking speed had the strongest association with SI among women aged between 65 and 74 years. In the study with 606 Finnish older women aged $68.0 \pm 1.8$ years [41], hip BMD including femoral neck, trochanter, and total proximal femur and lumbar spine BMD were correlated with PP. After adjusting for age, BMI, hormone therapy use, years since menopause, smoking status, and use of oral glucocorticoids, multivariate linear regression analysis showed that the strongest relationship was between hip BMD and OLS, followed by handgrip strength and OLS. The relationship of spine BMD and both OLS and handgrip strength was weak but remained significant, however, not significant with walking speed or STS, separately.

The findings in previous studies that the PP related to a specific extremity is associated with bone mass of that same extremity are well supported. The results from the Study of Osteoporotic Fractures conducted in 5,405 older women of non-African origins aged $73.8 \pm 5.3$ years also showed that handgrip strength was positively associated with higher BMD of various skeletal sites, but particularly that of the forearm [44]. With an increase of $5 \mathrm{~kg}$ of handgrip strength, distal radius and femoral neck BMD increased by $3 \%$ and $1 \%$ after controlling for age and weight, respectively. Additionally, faster walking speed $(0.2 \mathrm{~m} / \mathrm{s})$ was associated with an increase in 1\% BMD of femoral neck, but not at other skeletal sites. Similarly, Lindsey et al. [43] conducted a study in 116 postmenopausal Caucasian women aged $68.3 \pm 6.8$ years examining the relationship between different skeletal sites and measures of functionality, including normal and brisk walking speed, step length, OLS, timed chair sit-tostand test, and handgrip strength.

Results from multiple regression controlled for BMI, age of onset of menarche, total calcium intake, and total hours of physical activity showed that higher femoral neck, hip, and total BMD were significantly associated with faster walking speed, longer step length, and longer OLS time. On the other hand, stronger handgrip strength was significantly associated with all forearm BMD sites, but not with higher femoral neck BMD.

Notably, the relationship between handgrip strength and $\mathrm{BMD}$ of forearm was stronger than BMD of other skeletal sites in several studies. Another study with 2,619 community-dwelling older adults participating in the Health $\mathrm{ABC}$ study also investigated the correlation between handgrip strength and BMD of various skeletal sites [13]. Handgrip strength had the strongest positive correlation with upper limb BMD, followed by lower limb BMD or total and femoral neck BMD. Similarly, in another study [36] where bone mass was measured using an OsteoAnalyzer in 9,704 older women recruited from four clinical centers in the US, an increase in $5 \mathrm{~kg}$ of handgrip strength is correlated with a $3.5 \%$ increase in radius BMD (CI: 2.8, 4.3).

Other studies have examined handgrip strength from both hands, suggesting that nondominant handgrip strength could be a useful indicator to assess BMD. With 91 healthy active men and women living in Palo Alto, California, aged $70.0 \pm 0.7$ years [37], midradius and lumbar spine BMD were measured. In women, grip strength from both hands showed a significant relationship with spine and midradius $\mathrm{BMD}$, especially $\mathrm{BMD}$ of the dominant hand. In men, only midradius BMD showed a significantly positive correlation with handgrip strength from both hands. On the other hand, in the study with 649 postmenopausal Caucasian women aged $>65$ years living in Southern California [42], handgrip strength from both the dominant and nondominant arm was examined in relation to BMD of upper limb, as measured by single-photon absorptiometry, and of spine and hip as measured by DXA. With dominant handgrip strength, BMD of the hip showed the strongest positive association followed by wrist and spine BMD after adjusting for potential covariates including age, BMI, thiazide use, smoking, regular exercise, arthritis, years since menopause, and estrogen use. With radius BMD, the positive trend was observed, but significance was not reached. However, with the nondominant handgrip strength, a positive association with BMD was observed for all skeletal sites measured, including hip, radius, wrist, and spine.

Notably, the study with the Health ABC study cohort including 3041 community-dwelling older adults [79] showed that the association between hip region BMD and PP was sex and race specific, with the strongest association in black women, followed by white women and men. In this study, ANCOVA results adjusted for age, study site, height, weight, medication (thiazides, corticosteroids, estrogen for women), smoking pack-years, and physical activity showed that the mean value of femoral neck and trochanter BMD was significantly different among groups classified according to the quartiles of performance measures including timed chair STS, 6-meter walking speed, and OLS. The graded associations between femoral neck and trochanter BMD and groups classified by all PP measures were significant among black women, showing a higher BMD with better PP $(P<.05$, except standing balance and femoral neck BMD; $P=.163$ for trend). In white women, there was a moderate trend observed between femoral neck BMD and STS only. In white and black men, there was graded association found in trochanter BMD among the groups based on STS quartiles, but the difference among the groups was not significant. Therefore, the conclusions drawn included that the association between BMD and PP measures was strongest in black women, followed by white women and men. Since the analyses already included physical activity, other factors like nutritional, hormonal, or environmental could be considered to further explain the differences under the genetic basis among races. 


\section{Discussion}

In general, studies have shown that an increase in fat or decrease in muscle mass causes greater functional disability and lower PP. While muscle and fat mass have been considered an important factor of age-related decline in physical function, studies examining the relationship between fat/muscle mass and functionality have shown inconsistent results. Higher bone mineral density has tendency to correlate with better PP, although some studies showed that relationships depended on sex, race, and body compartment. Lorenzo [18] summarized several explanations of this inconsistency. First, because loss of muscle mass is inevitable with aging but also can occur due to weight loss from illness in the later stages of life, muscle mass may not be a good predictor of PP. Second, even though muscle mass is a good predictor of a muscle strength, it might not be as good of a predictor of physical strength as is muscle quality. Only a few studies have used CT to measure fat infiltration in muscle as a measure of muscle quality. Even though most studies selected in this review used DXA to measure body composition, each study used different ways to normalize or control for the absolute values of fat and muscle mass, which leads to different interpretation of data. For example, some studies used a fat index while others used the percentage of fat. Muscle mass was also normalized in several ways with height of stature or the leg for lower extremity. Finally, as mentioned above, the use of different instruments measuring PP can result in different outcomes. Even though handgrip strength was shown to be a good measure of overall PP, some studies also support that handgrip strength is more correlated with strength, body composition, and BMD of the upper extremity $[13,40]$.

Most of the studies are cross-sectional; so no long-term effects of the change in PP in different body composition categories have been investigated. Although functional capacity is known to dramatically decline with aging, most studies showed the correlations between body composition and PP without considering age and gender differences. Chronic diseases such as arthritis, back pain, and age-related vision decline which could affect walking speed were not considered as confounders in most studies. In addition, most studies included community-dwelling older adults, predominantly Caucasian, only two studies included African-American population $[56,80]$, and few studies were conducted in Asian populations $[10,77,78]$. Community-dwelling older adults might be healthier and more active than those living in long-term care facilities or nursing homes. Also, different races have different body composition and body size, which also might explain the differences in BMD among the racial groupings.

In conclusion, most studies showed a positive relationship between muscle mass and PP, especially in the lower extremities which are crucial for the mobility of the elderly. However, more studies regarding the relationships among obesity, adiposity, and PP are warranted. BMD has also shown a positive correlation with $\mathrm{PP}$, where stronger relationships have been shown in women than men. Although body composition changes with aging process in the opposite way, preserving muscle/bone mass and reducing excessive fat mass may be beneficial to keep PP and reduce functional disability in older adults. Standardized measurement such as the CS-PFP to predict PP for older populations needs to be incorporated into future studies to avoid a "ceiling" or "floor" effect. Validation studies of different measurements of PP across the age, sex, and race and establishing reference values of each item would be useful to identify the risk of physical disability in the later life and recommendation of weight management for older adults.

\section{Abbreviations}

AFMI: Appendicular fat mass index

ASMI: Appendicular skeletal muscle index

BBS: $\quad$ Berg balance scale

BIA: $\quad$ Bioelectrical impedance analysis

BMD: $\quad$ Bone mineral density

BMI: $\quad$ Body mass index

BUA: $\quad$ Broadband ultrasound attenuation

CS-PFP: Continuous-scale

CT: $\quad$ Computed tomography

DXA: Dual energy X-ray absorptiometry

The Health The health, aging and body composition

ABC PPB: study physical performance battery

HGS: $\quad$ Handgrip strength

LEP: $\quad$ Lower extremity performance

MRI: $\quad$ Magnetic resonance imaging

OLS: $\quad$ One-leg stance

QUS: Quantitative ultrasound bone densitometry

SI: $\quad$ Stiffness index

SLEPS: Summary lower-extremity performance scores

SPPB: $\quad$ The short Physical Performance Battery

PP: $\quad$ Physical performance

STS: $\quad$ Sit-to-stand

TUGT: Timed up-and-go test

US PPT: $\quad$ United states Physical Performance Test

WC: $\quad$ Waist circumference

WHR: Waist-to-hip ratio.

\section{Disclosures}

There were no financial benefits to the authors.

\section{Acknowledgment}

This work is supported in part by CSREES/National Research Initiative/USDA, no. 2004-05287.

\section{References}

[1] M. Brown, D. R. Sinacore, E. F. Binder, and W. M. Kohrt, "Physical and performance measures for the identification of mild to moderate frailty," Journals of Gerontology A, vol. 55, no. 6, pp. M350-M355, 2000.

[2] K. E. Ensrud, S. K. Ewing, B. C. Taylor et al., "Comparison of 2 frailty indexes for prediction of falls, disability, fractures, and 
death in older women," Archives of Internal Medicine, vol. 168, no. 4, pp. 382-389, 2008.

[3] E. Keeler, J. M. Guralnik, H. Tian, R. B. Wallace, and D. B. Reuben, "The impact of functional status on life expectancy in older persons," Journals of Gerontology A, vol. 65, no. 7, pp. 727-733, 2010.

[4] P. M. Cawthon, K. M. Fox, S. R. Gandra et al., "Do muscle mass, muscle density, strength, and physical function similarly influence risk of hospitalization in older adults?" Journal of the American Geriatrics Society, vol. 57, no. 8, pp. 1411-1419, 2009.

[5] E. Steinmetz, Americans With Disabilities: 2002, U.S. Census Bureau, Washington, DC, USA, 2006.

[6] J. Broadwin, D. Goodman-Gruen, and D. Slymen, "Ability of fat and fat-free mass percentages to predict functional disability in older men and women," Journal of the American Geriatrics Society, vol. 49, no. 12, pp. 1641-1645, 2001.

[7] M. Visser, J. Langlois, J. M. Guralnik et al., "High body fatness, but not low fat-free mass, predicts disability in older men and women: the cardiovascular health study," American Journal of Clinical Nutrition, vol. 68, no. 3, pp. 584-590, 1998.

[8] L. J. Launer, T. Harris, C. Rumpel, and J. Madans, "Body mass index, weight change, and risk of mobility disability in middleaged and older women: the epidemiologic follow-up study of NHANES I," Journal of the American Medical Association, vol. 271, no. 14, pp. 1093-1098, 1994.

[9] M. Visser, T. B. Harris, J. Langlois et al., "Body fat and skeletal muscle mass in relation to physical disability in very old men and women of the Framingham heart study," Journals of Gerontology A, vol. 53, no. 3, pp. M214-M221, 1998.

[10] J. Woo, J. Leung, and T. Kwok, "BMI, body composition, and physical functioning in older adults," Obesity, vol. 15, no. 7, pp. 1886-1894, 2007.

[11] J. S. W. Lee, T. W. Auyeung, T. Kwok, E. M. C. Lau, P. C. Leung, and J. Woo, "Associated factors and health impact of sarcopenia in older Chinese men and women: a cross-sectional study," Gerontology, vol. 53, no. 6, pp. 404-410, 2008.

[12] K. F. Reid, E. N. Naumova, R. J. Carabello, E. M. Phillips, and R. A. Fielding, "Lower extremity muscle mass predicts functional performance in mobility-limited elders," Journal of Nutrition, Health and Aging, vol. 12, no. 7, pp. 493-498, 2008.

[13] D. R. Taaffe, J. A. Cauley, M. Danielson et al., "Race and sex effects on the association between muscle strength, soft tissue, and bone mineral density in healthy elders: the health, aging, and body composition study," Journal of Bone and Mineral Research, vol. 16, no. 7, pp. 1343-1352, 2001.

[14] J. A. Cauley, R. L. Fullman, K. L. Stone et al., "Factors associated with the lumbar spine and proximal femur bone mineral density in older men," Osteoporosis International, vol. 16, no. 12, pp. 1525-1537, 2005.

[15] J. A. Hodgdon, K. E. Friedl, M. B. Beckett, K. A. Westphal, and R. L. Shippee, "Use of bioelectrical impedance analysis measurements as predictors of physical performance," American Journal of Clinical Nutrition, vol. 64, no. 3, supplement, pp. 463S-468S, 1996.

[16] D. A. Kerr, S. Papalia, A. Morton, I. Dick, S. Dhaliwal, and R. L. Prince, "Bone mass in young women is dependent on lean body mass," Journal of Clinical Densitometry, vol. 10, no. 3, pp. 319-326, 2007.

[17] L. M. Salamone, T. Fuerst, M. Visser et al., "Measurement of fat mass using DEXA: a validation study in elderly adults," Journal of Applied Physiology, vol. 89, no. 1, pp. 345-352, 2000.
[18] C. Lorenzo, "Body composition and physical function in older adults," Obesity, vol. 17, no. 2, pp. 211-212, 2009.

[19] T. B. Harris, M. Visser, J. Everhart et al., "Waist circumference and sagittal diameter reflect total body fat better than visceral fat in older men and women. The Health, Aging and Body Composition Study," Annals of the New York Academy of Sciences, vol. 904, pp. 462-473, 2000.

[20] I. Janssen, P. T. Katzmarzyk, and R. Ross, "Body mass index, waist circumference, and health risk: evidence in support of current national institutes of health guidelines," Archives of Internal Medicine, vol. 162, no. 18, pp. 2074-2079, 2002.

[21] M. C. Pouliot, J. P. Despres, S. Lemieux et al., "Waist circumference and abdominal sagittal diameter: best simple anthropometric indexes of abdominal visceral adipose tissue accumulation and related cardiovascular risk in men and women," American Journal of Cardiology, vol. 73, no. 7, pp. 460-468, 1994.

[22] I. R. Pateyjohns, G. D. Brinkworth, J. D. Buckley, M. Noakes, and P. M. Clifton, "Comparison of three bioelectrical impedance methods with DXA in overweight and obese men," Obesity, vol. 14, no. 11, pp. 2064-2070, 2006.

[23] J. M. Guralnik, E. M. Simonsick, L. Ferrucci et al., "A short physical performance battery assessing lower extremity function: association with self-reported disability and prediction of mortality and nursing home admission," Journals of Gerontology, vol. 49, no. 2, pp. M85-M94, 1994.

[24] E. M. Simonsick, A. B. Newman, M. C. Nevitt et al., "Measuring higher level physical function in well-functioning older adults: expanding familiar approaches in the health $\mathrm{ABC}$ study," Journals of Gerontology A, vol. 56, no. 10, pp. M644M649, 2001.

[25] J. R. Sharkey, C. Giuliani, P. S. Haines, L. G. Branch, J. Busby-Whitehead, and N. Zohoori, "Summary measure of dietary musculoskeletal nutrient (calcium, vitamin D, magnesium, and phosphorus) intakes is associated with lowerextremity physical performance in homebound elderly men and women," The American Journal of Clinical Nutrition, vol. 77, no. 4, pp. 847-856, 2003.

[26] D. B. Reuben and A. L. Siu, "An objective measure of physical function of elderly outpatients: the Physical Performance Test," Journal of the American Geriatrics Society, vol. 38, no. 10, pp. 1105-1112, 1990.

[27] I. Mattiasson-Nilo, U. Sonn, K. Johannesson, G. GosmanHedstrom, G. B. Persson, and G. Grimby, "Domestic activities and walking in the elderly: evaluation from a 30-hour heart rate recording," Aging-Clinical and Experimental Research, vol. 2, no. 2, pp. 191-198, 1990.

[28] M. E. Cress, D. M. Buchner, K. A. Questad, P. C. Esselman, B. J. DeLateur, and R. S. Schwartz, "Continuous-scale physical functional performance in healthy older adults: a validation study," Archives of Physical Medicine and Rehabilitation, vol. 77, no. 12, pp. 1243-1250, 1996.

[29] M. A. Krieg, R. Barkmann, S. Gonnelli et al., "Quantitative ultrasound in the management of osteoporosis: the 2007 ISCD official positions," Journal of Clinical Densitometry, vol. 11, no. 1, pp. 163-187, 2008.

[30] L. B. Panton, J. D. Kingsley, T. Toole et al., "A comparison of physical functional performance and strength in women with fibromyalgia, age- and weight-matched controls, and older women who are healthy," Physical Therapy, vol. 86, no. 11, pp. 1479-1488, 2006.

[31] S. W. Arnett, J. H. Laity, S. K. Agrawal, and M. E. Cress, "Aerobic reserve and physical functional performance in older adults," Age and Ageing, vol. 37, no. 4, pp. 384-389, 2008. 
[32] D. B. Reuben, A. L. Siu, and S. Kimpau, "The predictive validity of self-report and performance-based measures of function and health," Journals of Gerontology, vol. 47, no. 4, pp. M106-M110, 1992.

[33] S. E. Sherman and D. Reuben, "Measures of functional status in community-dwelling elders," Journal of General Internal Medicine, vol. 13, no. 12, pp. 817-823, 1998.

[34] S. Fisher, K. J. Ottenbacher, J. S. Goodwin, J. E. Graham, and G. V. Ostir, "Short physical performance battery in hospitalized older adults," Aging-Clinical and Experimental Research, vol. 21, no. 6, pp. 445-452, 2009.

[35] J. R. Sharkey, C. Giuliani, P. S. Haines, L. G. Branch, J. Busby-Whitehead, and N. Zohoori, "Summary measure of dietary musculoskeletal nutrient (calcium, vitamin D, magnesium, and phosphorus) intakes is associated with lowerextremity physical performance in homebound elderly men and women," The American Journal of Clinical Nutrition, vol. 77, no. 4, pp. 847-856, 2003.

[36] D. C. Bauer, W. S. Browner, J. A. Cauley et al., "Factors associated with appendicular bone mass in older women," Annals of Internal Medicine, vol. 118, no. 9, pp. 657-665, 1993.

[37] W. C. Bevier, R. A. Wiswell, G. Pyka, K. C. Kozak, K. M. Newhall, and R. Marcus, "Relationship of body composition, muscle strength, and aerobic capacity to bone mineral density in older men and women," Journal of Bone and Mineral Research, vol. 4, no. 3, pp. 421-432, 1989.

[38] R. W. Bohannon, "Hand-grip dynamometry predicts future outcomes in aging adults," Journal of Geriatric Physical Therapy, vol. 31, no. 1, pp. 3-10, 2008.

[39] M. Estrada, A. Kleppinger, J. O. Judge, S. J. Walsh, and G. A. Kuchel, "Functional impact of relative versus absolute sarcopenia in healthy older women," Journal of the American Geriatrics Society, vol. 55, no. 11, pp. 1712-1719, 2007.

[40] K. T. Foley, T. M. Owings, M. J. Pavol, and M. D. Grabiner, "Maximum grip strength is not related to bone mineral density of the proximal femur in older adults," Calcified Tissue International, vol. 64, no. 4, pp. 291-294, 1999.

[41] M. Kärkkäinen, T. Rikkonen, H. Kröger et al., "Physical tests for patient selection for bone mineral density measurements in postmenopausal women," Bone, vol. 44, no. 4, pp. 660-665, 2009.

[42] D. Kritz-Silverstein and E. Barrett-Connor, "Grip strength and bone mineral density in older women," Journal of Bone and Mineral Research, vol. 9, no. 1, pp. 45-51, 1994.

[43] C. Lindsey, R. A. Brownbill, R. A. Bohannon, and J. Z. Ilich, "Association of physical performance measures with bone mineral density in postmenopausal women," Archives of Physical Medicine and Rehabilitation, vol. 86, no. 6, pp. 11021107, 2005.

[44] E. S. Orwoll, D. C. Bauer, T. M. Vogt, and K. M. Fox, "Axial bone mass in older women," Annals of Internal Medicine, vol. 124, no. 2, pp. 187-196, 1996.

[45] H. Payette, N. Hanusaik, V. Boutier, J. A. Morais, and K. GrayDonald, "Muscle strength and functional mobility in relation to lean body mass in free-living frail elderly women," European Journal of Clinical Nutrition, vol. 52, no. 1, pp. 45-53, 1998.

[46] A. N. Pedersen, L. Ovesen, M. Schroll, K. Avlund, and P. Era, "Body composition of 80-years old men and women and its relation to muscle strength, physical activity and functional ability," Journal of Nutrition, Health and Aging, vol. 6, no. 6, pp. 413-420, 2002.
[47] Y. Rolland, V. Lauwers-Cances, M. Cournot et al., "Sarcopenia, calf circumference, and physical function of elderly women: a cross-sectional study," Journal of the American Geriatrics Society, vol. 51, no. 8, pp. 1120-1124, 2003.

[48] Y. Rolland, V. Lauwers-Cances, M. Pahor, J. Fillaux, H. Grandjean, and B. Vellas, "Muscle strength in obese elderly women: effect of recreational physical activity in a crosssectional study," American Journal of Clinical Nutrition, vol. 79, no. 4, pp. 552-557, 2004.

[49] J. Desrosiers, R. Hébert, G. Bravo, and A. Rochette, "Agerelated changes in upper extremity performance of elderly people: a longitudinal study," Experimental Gerontology, vol. 34, no. 3, pp. 393-405, 1999.

[50] R. H. Hyatt, M. N. Whitelaw, A. Bhat, S. Scott, and J. D. Maxwell, "Association of muscle strength with functional status of elderly people," Age and Ageing, vol. 19, no. 5, pp. 330-336, 1990.

[51] D. A. Kallman, C. C. Plato, and J. D. Tobin, "The role of muscle loss in the age-related decline of grip strength: cross-sectional and longitudinal perspectives," Journals of Gerontology, vol. 45, no. 3, pp. M82-M88, 1990.

[52] E. J. Metter, R. Conwit, J. Tobin, and J. L. Fozard, "Ageassociated loss of power and strength in the upper extremities in women and men," Journals of Gerontology A, vol. 52, no. 5, pp. B267-B276, 1997.

[53] D. A. Skelton, C. A. Greig, J. M. Davies, and A. Young, "Strength, power and related functional ability of healthy people aged 65-89 years," Age and Ageing, vol. 23, no. 5, pp. 371-377, 1994.

[54] T. Rantanen, K. Masaki, D. Foley, G. Izmirlian, L. White, and J. M. Guralnik, "Grip strength changes over $27 \mathrm{yr}$ in JapaneseAmerican men," Journal of Applied Physiology, vol. 85, no. 6, pp. 2047-2053, 1998.

[55] T. Rantanen, P. Era, and E. Heikkinen, "Physical activity and the changes in maximal isometric strength in men and women from the age of 75 to 80 years," Journal of the American Geriatrics Society, vol. 45, no. 12, pp. 1439-1535, 1997.

[56] M. Visser, D. J. H. Deeg, P. Lips, T. B. Harris, and L. M. Bouter, "Skeletal muscle mass and muscle strength in relation to lower-extremity performance in older men and women," Journal of the American Geriatrics Society, vol. 48, no. 4, pp. 381-386, 2000.

[57] S. A. Snih, K. S. Markides, L. Ray, G. V. Ostir, and J. S. Goodwin, "Handgrip strength and mortality in older Mexican Americans," Journal of the American Geriatrics Society, vol. 50, no. 7, pp. 1250-1256, 2002.

[58] P. Laukkanen, E. Heikkinen, and M. Kauppinen, "Muscle strength and mobility as predictors of survival in 75-84-yearold people," Age and Ageing, vol. 24, no. 6, pp. 468-473, 1995.

[59] P. Phillips, "Grip strength, mental performance and nutritional status as indicators of mortality risk among female geriatric patients," Age and Ageing, vol. 15, no. 1, pp. 53-56, 1986.

[60] T. Rantanen, T. Harris, S. G. Leveille et al., "Muscle strength and body mass index as long-term predictors of mortality in initially healthy men," Journals of Gerontology A, vol. 55, no. 3, pp. M168-M173, 2000.

[61] D. R. Bouchard, S. Beliaeff, I. J. Dionne, and M. Brochu, "Fat mass but not fat-free mass is related to physical capacity in well-functioning older individuals: nutrition as a determinant of successful aging (NuAge)—the Quebec longitudinal study," Journals of Gerontology A, vol. 62, no. 12, pp. 1382-1388, 2007. 
[62] C. M. Jankowski, W. S. Gozansky, R. E. Van Pelt et al., "Relative contributions of adiposity and muscularity to physical function in community-dwelling older adults," Obesity, vol. 16, no. 5, pp. 1039-1044, 2008.

[63] J. R. Sharkey and L. G. Branch, "Gender differences in physical performance, body composition, and dietary intake in homebound elders," Journal of Women and Aging, vol. 16, no. 3-4, pp. 71-90, 2004.

[64] R. J. Valentine, M. M. Misic, K. S. Rosengren, J. A. Woods, and E. M. Evans, "Sex impacts the relation between body composition and physical function in older adults," Menopause, vol. 16, no. 3, pp. 518-523, 2009.

[65] R. W. Bohannon, P. J. Brennan, L. S. Pescatello, L. Marschke, S. Hasson, and M. Murphy, "Adiposity of elderly women and its relationship with self-reported and observed physical performance," Journal of Geriatric Physical Therapy, vol. 28, no. 1, pp. 10-13, 2005.

[66] A. B. Newman, V. Kupelian, M. Visser et al., "Sarcopenia: alternative definitions and associations with lower extremity function," Journal of the American Geriatrics Society, vol. 51, no. 11, pp. 1602-1609, 2003.

[67] M. M. Misic, K. S. Rosengren, J. A. Woods, and E. M. Evans, "Muscle quality, aerobic fitness and fat mass predict lowerextremity physical function in community-dwelling older adults," Gerontology, vol. 53, no. 5, pp. 260-266, 2007.

[68] S. Sipila and H. Suominen, "Knee extension strength and walking speed in relation to quadriceps muscle composition and training in elderly women," Clinical Physiology, vol. 14, no. 4, pp. 433-442, 1994.

[69] M. Visser, S. B. Kritchevsky, B. H. Goodpaster et al., "Leg muscle mass and composition in relation to lower extremity performance in men and women aged 70 to 79: the Health, Aging and Body Composition Study," Journal of the American Geriatrics Society, vol. 50, no. 5, pp. 897-904, 2002.

[70] G. E. Hicks, E. M. Simonsick, T. B. Harris et al., "Crosssectional associations between trunk muscle composition, back pain, and physical function in the health, aging and body composition study," Journals of Gerontology A, vol. 60, no. 7, pp. 882-887, 2005.

[71] B. K. S. Chan, L. M. Marshall, K. M. Winters, K. A. Faulkner, A. V. Schwartz, and E. S. Orwoll, "Incident fall risk and physical activity and physical performance among older men: the osteoporotic fractures in men study," American Journal of Epidemiology, vol. 165, no. 6, pp. 696-703, 2007.

[72] M. Morita, N. Takamura, Y. Kusano et al., "Relationship between falls and physical performance measures among community-dwelling elderly women in Japan," AgingClinical and Experimental Research, vol. 17, no. 3, pp. 211-216, 2005.

[73] J. K. Berry, C. A. Vitalo, J. L. Larson, M. Patel, and MI. J. Kim, "Respiratory muscle strength in older adults," Nursing Research, vol. 45, no. 3, pp. 154-159, 1996.

[74] C. Castaneda, J. M. Charnley, W. J. Evans, and M. C. Crim, "Elderly women accommodate to a low-protein diet with losses of body cell mass, muscle function, and immune response," American Journal of Clinical Nutrition, vol. 62, no. 1, pp. 30-39, 1995.

[75] R. Roubenoff, "The pathophysiology of wasting in the elderly," Journal of Nutrition, vol. 129, no. 1, supplement, pp. 256S259S, 1999.

[76] O. R. Madsen, U. B. Lauridsen, and O. H. Sorensen, "Quadriceps strength in women with a previous hip fracture: relationships to physical ability and bone mass," Scandinavian Journal of Rehabilitation Medicine, vol. 32, no. 1, pp. 37-40, 2000.

[77] W. Sun, M. Watanabe, Y. Tanimoto et al., "Assessment of the best gait parameter in relation to bone status in communitydwelling young-old and old-old women in Japan," Archives of Gerontology and Geriatrics, vol. 49, no. 1, pp. 158-161, 2009.

[78] Y. J. Tang, W. H. H. Sheu, PI. H. Liu, W. J. Lee, and Y. T. Chen, "Positive associations of bone mineral density with body mass index, physical activity, and blood triglyceride level in men over 70 years old: a TCVGHAGE study," Journal of Bone and Mineral Metabolism, vol. 25, no. 1, pp. 54-59, 2007.

[79] D. R. Taaffe, E. M. Simonsick, M. Visser et al., "Lower extremity physical performance and hip bone mineral density in elderly black and white men and women: cross-sectional associations in the health $\mathrm{ABC}$ study," Journals of Gerontology A, vol. 58, no. 10, pp. 934-942, 2003.

[80] M. Sowers, M. L. Jannausch, M. Gross et al., "Performancebased physical functioning in African-American and Caucasian women at midlife: considering body composition, quadriceps strength, and knee osteoarthritis," American Journal of Epidemiology, vol. 163, no. 10, pp. 950-958, 2006. 


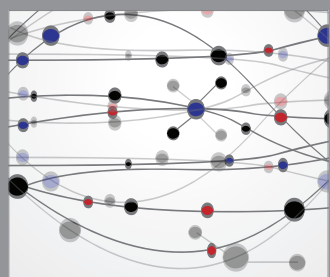

The Scientific World Journal
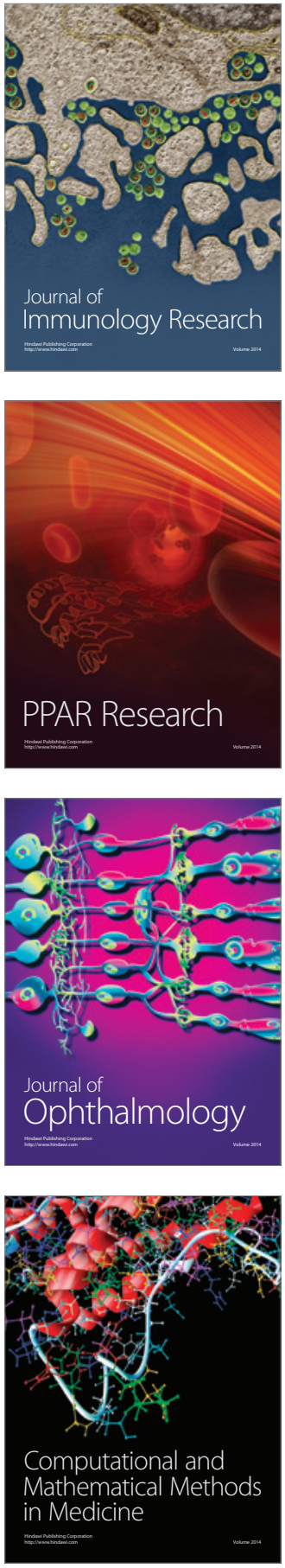

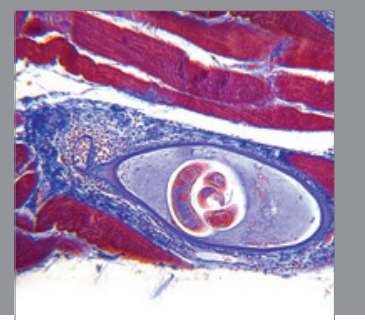

Gastroenterology

Research and Practice
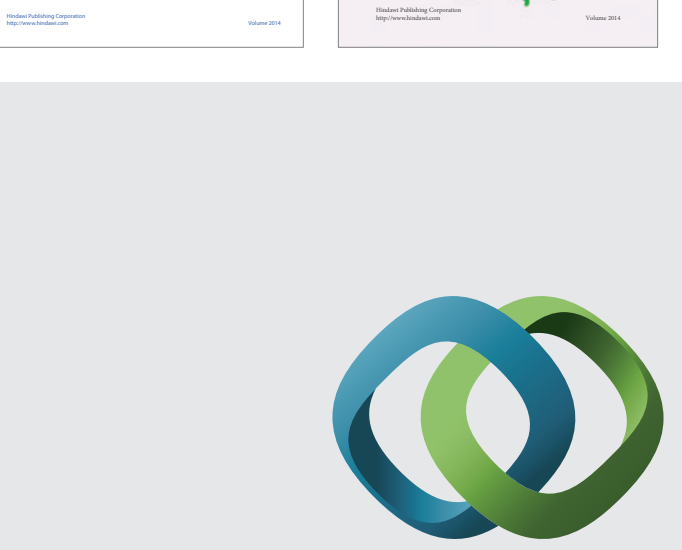

\section{Hindawi}

Submit your manuscripts at

http://www.hindawi.com
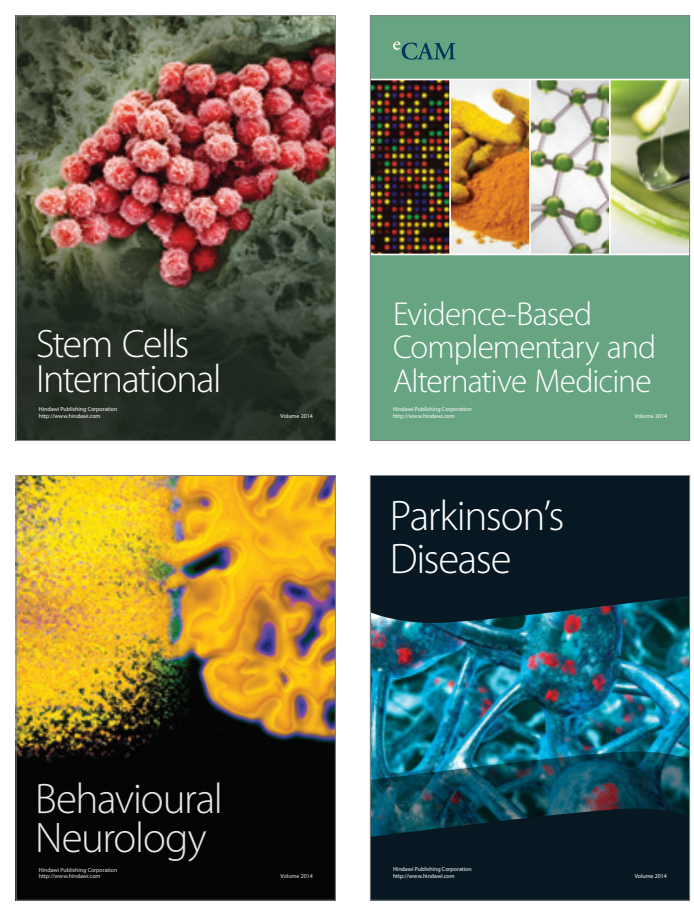

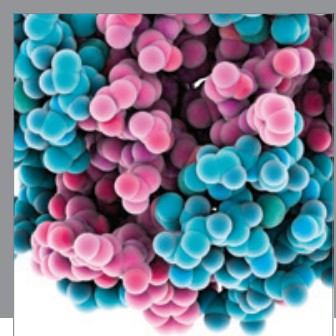

Journal of
Diabetes Research

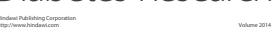

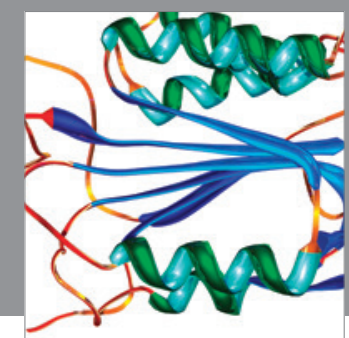

Disease Markers
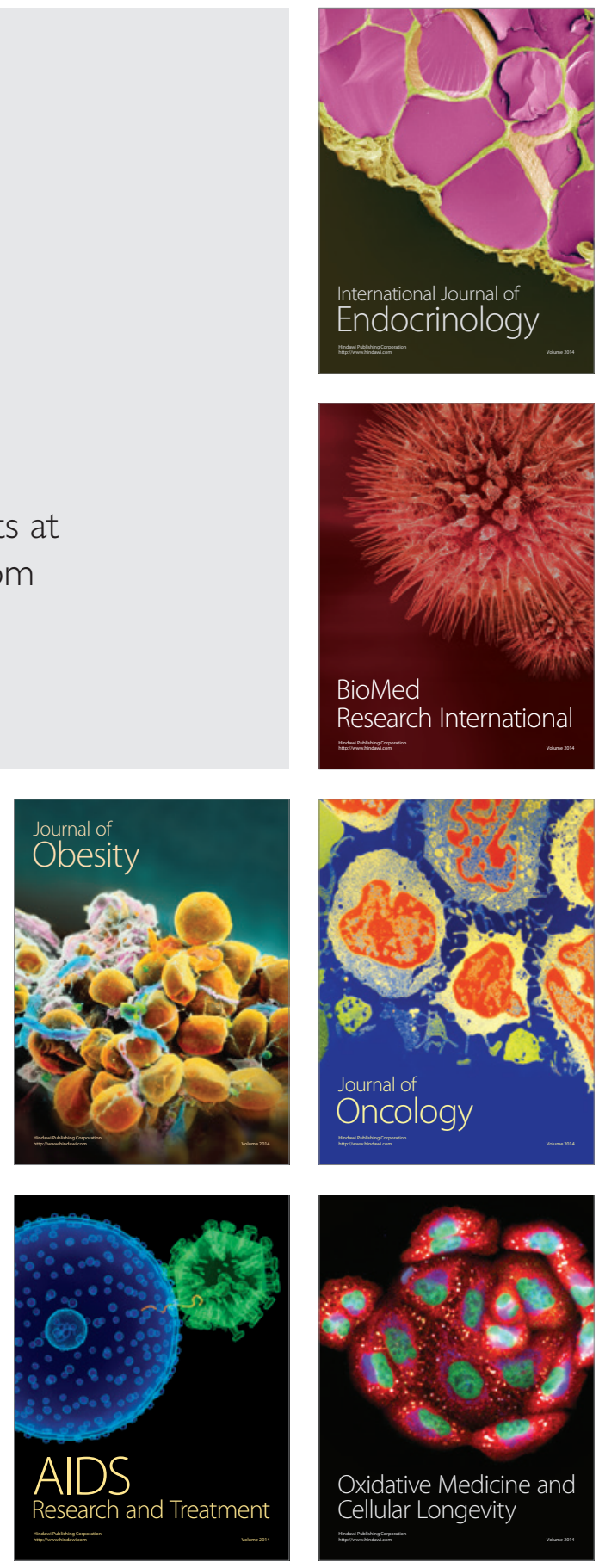